\title{
Nutritional Analysis and Phytochemical Evaluation of Bitter Gourd (Momordica Charantia) from Bangladesh
}

\author{
Rashu Barua ${ }^{1,2}$, Md. Ehsan Uddin Talukder, Mohammad Sayedul Islam¹, Farhana Yesmin ${ }^{2}$, Kanchan \\ Chakma $^{1}$, and Md. Golam Kabir ${ }^{1}$, Robiul Hasan Bhuiyan ${ }^{1, *}$ \\ ${ }^{1}$ Department of Biochemistry and Molecular Biology, University of Chittagong \\ Chittagong-4331, Bangladesh \\ ${ }^{2}$ Department of Molecular Biochemistry, Nagoya University Graduate School of Medicine \\ Nagoya-466-0065, Japan
}

*Corresponding author's email: biochemistrobi79 [AT] gmail.com

\begin{abstract}
Momordica charantia (M. charantia) is commonly referred to as Bitter Gourd, Karela and balsampear, is a very familiar vegetable and widely cultivate in Bangladesh. It has long been used as a traditional medicine for some ailments. Nutritional compositions and phytochemical constituents of two selected hybrid varieties of $M$. charantia (TIA and GOJNEE) from Bangladesh were analysed using standard analytical methods. The proximate composition like moisture, ash, crude lipid, crude fibre and crude protein contents were showed as percentage. The study results showed that the two varieties of this M. charantia are good source of minerals such as Calcium (Ca), Potassium (K), Magnesium (Mg), Iron (Fe) and Chromium (Cr). Calcium and iron concentrations were higher in both varieties. And their concentrations were 2.35 and 1.04 ppm in GOJNEE, and 2.24 and 0.87 ppm in TIA, respectively. Phytochemicals constituents like alkaloids, tannins, flavonoids and saponins were found in both varieties of M. charantia. Quantity of alkaloids, flavonoids and saponin were 0.05, 2.001 and $5.02 \%$ in seeds of GOJNEE and $0.012,1.72$ and $3.27 \%$ in seed of TIA. Total phenolic content was also determined and found that the highest contents were in ethanol and ethyl acetate extracts in both varieties. Our study result indicates the presence of nutritional and phytochemical constituents which are beneficial for our health along with the medicinal values.
\end{abstract}

Keywords---- Momordica charantia, Karela, nutritional analysis, phytochemical evaluation

\section{INTRODUCTION}

In recent years malnutrition is a common topic in developing countries. Distinct types of evidence suggest that research into nutrition and nutraceuticals have centralized mainly on plant derived products such as leaves, fruits, seeds etc. (Yoshime et al., 2016) Among the plant derived products, vegetables play a vital role to meet the nutritional necessity of people in Bangladesh. But for the unawareness of the people, they do not know the nutritive value of vegetables and fruits. So, most of the people in Bangladesh are suffering in malnutrition (Ullah et al.,2011).

Herbs and other dietary supplements are used as alternative treatment against different diseases. The medicine involves in this treatment is known as alternative and complementary medicine. From the ancient period, traditional medicinal plants and their derivatives are used as therapeutic agents for human kind. The world health organization (WHO) had listed that one fifty species of medicinal plants are used as commercially for medicinal purpose. Among the 150 species, bitter gourd is most commonly used as therapeutic purpose (Joseph et al., 2013).

Momordica charantia also known as Bitter Melon, Bitter Cucumber, Karela and Balsam-pear, is a tropical vegetable, commonly found in Bangladesh. It is hardly expensive and especially used as a folk medicine. The tree has long leaves, yellow flowers, and elongated fruits that resemble a gourd or cucumber belongs to Cucurbitaceae family (Basch et al., 2003; Marr et al., 2004). Traditionally, the plant extracts of $M$. charantia is used for the treatment of hyperglycaemia, cancer, hypercholesterolemia, heart diseases and other immunological diseases. Because, M. charantia contain a hypoglycaemic compound named charantin and different antioxidants such as carotinoid, cryptoxanthin, vitamin C, vitamin $\mathrm{E}$ and varieties of phenolic compounds (Behera et al., 2007). It has moderate antioxidant and potent cytotoxic activities (Barua et al., 2014).

Many of the traditional plants are used with no attention paid to their nutritional values. Till now there are a few data available on the nutrient contents of hybrid bitter gourd varieties cultivated in Bangladesh. In this study, two varieties of cultivated bitter gourds were used. They are locally known as GOJNEE and TIA. Thus, the study was to exploit the nutritional composition as well as biologically important phytochemical profile of two selected hybrid varieties of M. charantia. 


\section{Collection of samples from two varieties of $M$. charantia}

\section{METHODS AND MATERIALS}

The seeds of TIA variety were collected from the society nursery, and another hybrid variety of M. charantia, GOJNEE was collected from the local market of the district of Chittagong, Bangladesh. The sample was collected in the month of March-April, 2011. The study was conducted in 2011 at the Department of Biochemistry and Molecular Biology in the University of Chittagong, Chittagong, Bangladesh. The varieties were identified by researcher at the Department of Botany, University of Chittagong. After washing the samples, the seeds were separated and removed the foreign materials. Then, the fruits (pericarp) were used for experimental analysis. The fruits (pericarp) were air-dried for 5 days and made into powder by using electrical grinder. Dried powder was stored in tight-seal dark containers at $25^{\circ} \mathrm{C}$ until needed.

\section{Proximate analysis}

The moisture content of $M$. charantia was carried out according to the method of Association of Official Analytical Chemist (AOAC, 1980), and Ash was determined by the standard method of AOAC (1995). The other nutrients like total proteins were determined by Micro-Kjeldahl method of AOAC (1960) using 6.25 factor to calculate protein content from nitrogen content, and crude fibre content was determined by AOAC (1980) while Lipid content by the method of AOAC (1980).

\section{Estimation of Mineral content}

The minerals content in the M. charantia were analysed by the method as described in analytical methods (Petersen, 2002).

\section{Phytochemical screening}

Phytochemical screening of the petroleum ether, ethyl acetate and ethanol extracts of two varieties of M. charantia fruits were carried out. The presence of alkaloids, tannins, flavonoids, saponins, and anthraquinones were carried out according to the methods of Sofowora (2006), Harbone (1991), Trease and Evans (2002) and Edeoga et al. (2005).

\section{Alkaloid Screening}

Determination of alkaloid was performed using the procedure put forward by Harborne (1973) as described by Edeoga $e t$ al. (2005). Briefly, five grams (5 g) of the powdered sample were weighed into $250 \mathrm{ml}$ beaker. Acetic acid (10\%) in ethanol was then added. The mixture was covered and allowed to incubate for $4 \mathrm{~h}$. This was then filtered, and the extract concentrated on a water bath to $1 / 4$ of the original volume. Thereafter, concentrated ammonium hydroxide added drop wise until precipitation was completed. The solution was then allowed to settle and the precipitate was collected, then washed with diluted ammonium hydroxide and filtered. The residue was dried and weighed was alkaloid.

\section{Flavonoids Screening}

Flavonoids were determined by the methods developed by Boham and Kocipaiabyazan (1994). Briefly, $10 \mathrm{~g}$ of the plant sample was extracted repeatedly with $100 \mathrm{ml}$ of $80 \%$ aqueous methanol at room temperature. The whole solution was then filtered using Whatman No.42 $(125 \mathrm{~mm})$ filter paper. The filtrate was later transferred into crucible and evaporated to dryness over a water bath and weighed to a constant weight. The weighed was flavonoids.

\section{Saponins Screening}

Saponins were determined according to the method described by Obadoni and Ochuko (2001). Based on this method, 10 $\mathrm{g}$ of the powdered sample for each plant species was transferred into a conical flask, and $50 \mathrm{ml}$ of $20 \%$ aqueous ethanol was added. This was heated over a hot water bath for $4 \mathrm{~h}$ while stirring continuously at $55^{\circ} \mathrm{C}$. Thereafter, the mixture was filtered and the residue re-extracted with another $100 \mathrm{ml}$ of $20 \%$ ethanol. The combined extracts were reduced to 40 $\mathrm{ml}$ using water bath at $90^{\circ} \mathrm{C}$. Then, the concentrate was transferred into a $250 \mathrm{ml}$ separatory funnel. Diethyl ether $10 \mathrm{ml}$ was added to the funnel, and the mixture was shaken vigorously. The aqueous layer was recovered after the ether layer was discarded. The purification process was repeated. In addition, $30 \mathrm{ml}$ of $\mathrm{n}$-butanol was added. The combined nbutanol extract was washed twice using $5 \mathrm{ml}$ of $5 \%$ aqueous sodium chloride, and the remaining solution was then heated in a water bath.

\section{Phenolic content analysis in different extracts}

The total phenolic content of the M. charantia extracts was determined using the Folin- Ciocalteu reagent (Mills, 1981). The reaction mixture was contained: $1 \mathrm{ml}$ of diluted extract $(200 \mathrm{mg} / \mathrm{ml}), 5 \mathrm{ml}$ of freshly prepared diluted Folin Ciocalteu reagent and $4 \mathrm{ml}$ of $7.5 \%$ sodium carbonate. Mixtures were kept in dark at ambient conditions for $1 \mathrm{~h}$ to complete the reaction. The absorbance at $765 \mathrm{~nm}$ was measured using a spectrophotometer (Shimadzu UV PC-1600). Gallic acid was used as standard, and the results were presented as dry weight basis with $\mu \mathrm{g}$ gallic acid equivalent (GAE)/mg of sample. 


\section{STATISTICAL ANALYSIS}

The data obtained in these investigations were subjected to statistical analysis. The data was analyzed using SPSS. All results are expressed as Mean $\pm \mathrm{SD}$.

\section{RESULT}

This study obtained the results of nutrient analysis, mineral content and the phytochemicals in M. charantia. Analysis of proximate content showed that the amount of moisture, ash, total protein, crude fat and crude fibre content were present in these two varieties (GOJNEE and TIA) of $M$. Charantia fruits. It appears that the content of moisture, ash, total protein, crude fat and crude fibre were $98.19,0.95,1.02,0.60$ and 2.19 percent in GOJNEE, and 94.05, 0.79, 0.92, 0.81 and 1.25 percent in TIA as shown in Table 1.

Table 1: Selected nutrients in two hybrid varieties of $M$. Charantia $(\%)^{*}$

\begin{tabular}{|c|c|c|c|}
\hline Sl. No & Chemical constituents & \multicolumn{2}{|c|}{ M. charantia hybrid varieties } \\
\cline { 3 - 4 } & & GOJNEE & TIA \\
\hline 1. & Moisture & $93.19 \pm 0.04$ & $94.05 \pm 0.06$ \\
\hline 2. & Ash & $0.95 \pm 0.04$ & $0.79 \pm 0.05$ \\
\hline 3. & Total Protein & $1.02 \pm 0.03$ & $0.92 \pm 0.3$ \\
\hline 4. & Crude Fat & $0.60 \pm 0.02$ & $0.81 \pm .02$ \\
\hline 5. & Crude fibre & $2.19 \pm 0.04$ & $1.25 \pm 0.03$ \\
\hline
\end{tabular}

$* \mathrm{FWB}=$ Fresh weight basis

The mineral contents of two varieties of $M$. Charantia fruits were analysed and the result was represented in Table 2. The most abundant mineral was calcium as 2.35 and $2.24 \mathrm{ppm}$ in GOJNEE and TIA, respectively. The concentration of other minerals like potassium, magnesium, iron and Chromium was 0.84, 0.57, 1.04 and 0.0037 ppm in GOJNEE, and $0.78,0.64,0,87$ and $0.0028 \mathrm{ppm}$ in TIA, respectively (Table 2).

Table 2: Selected minerals in two hybrid varieties of $M$. charantia $(\mathrm{ppm})$

\begin{tabular}{|c|c|c|c|}
\hline Sl. No & Minerals & \multicolumn{2}{|c|}{ M. charantia hybrid varieties } \\
\cline { 2 - 3 } & & GOJNEE & TIA \\
\hline 1. & Calcium $(\mathrm{Ca})$ & $2.35 \pm 0.25$ & $2.24 \pm 0.18$ \\
\hline 2. & Potassium $(\mathrm{K})$ & $0.84 \pm 0.06$ & $0.78 \pm 0.07$ \\
\hline 3. & Magnesium $(\mathrm{Mg})$ & $0.57 \pm .08$ & $0.64 \pm 0.01$ \\
\hline 4. & Iron $(\mathrm{Fe})$ & $1.04 \pm 0.06$ & $0.87 \pm 0.08$ \\
\hline 5. & Chromium $(\mathrm{Cr})$ & $0.0037 \pm 0.00046$ & $0.0028 \pm 0.00056$ \\
\hline
\end{tabular}

The phytochemical screening of the two hybrid varieties of $M$. Charantia was analysed, and found that the presence of alkaloids, flavonoids, tannins and saponins were in the extract of ethanol, ethyl acetate and petroleum ether of both GOJNEE and TIA (Table 3). No alkaloid was observed in petroleum ether in both varieties. It was clearly indicated that the two varieties of $M$. Charantia extracts contained almost the similar types of phytochemical constituents. The percentage of alkaloids, flavonoids and saponins were 0.05, 2.001 and 5.02 in GOJNEE, and 0.012, 1.72 and 3.27 in TIA, respectively (Table 4).

Table 3: Phytochemical Screening of two selected hybrid Varieties of M. charantia

\begin{tabular}{|c|c|c|c|c|c|c|c|}
\hline \multirow{3}{*}{ S1. No } & \multirow{3}{*}{ Phytochemicals } & \multicolumn{6}{|c|}{ M. charantia hybrid varieties } \\
\hline & & \multicolumn{3}{|c|}{ GOJNEE } & \multicolumn{3}{|c|}{ TIA } \\
\hline & & $\begin{array}{l}\text { Ethanol } \\
\text { Extract }\end{array}$ & $\begin{array}{l}\text { Ethyl } \\
\text { acetate } \\
\text { Extract }\end{array}$ & $\begin{array}{l}\text { Petroleum } \\
\text { ether } \\
\text { Extract }\end{array}$ & $\begin{array}{l}\text { Ethanol } \\
\text { Extract }\end{array}$ & $\begin{array}{l}\text { Ethyl } \\
\text { acetate } \\
\text { Extract }\end{array}$ & $\begin{array}{l}\text { Petroleum } \\
\text { ether } \\
\text { Extract }\end{array}$ \\
\hline 1. & Alkaloids & + & + & - & + & + & - \\
\hline 2. & Flavonoids & + & + & + & + & + & + \\
\hline 3. & Tannins & + & + & + & + & + & + \\
\hline 4. & Saponins & + & + & + & + & + & + \\
\hline
\end{tabular}


Table 4: Quantitative (percent) phytochemical evaluation of seeds of both varieties (gm/100gm)

\begin{tabular}{|c|c|c|c|}
\hline Variety & Alkaloid & Flavonoid & Saponin \\
\hline GOJNEE & 0.05 & 2.001 & 5.02 \\
\hline TIA & 0.012 & 1.72 & 3.27 \\
\hline
\end{tabular}

The total phenolic content (TPC) was expressed as gallic acid equivalents phenol compounds were reported as gallic acid equivalents (GAE) by reference to a standard curve $\left(y=0.003 x+0.077 ; \mathrm{r}^{2}=0.997\right)$ (data not shown). No significant differences were observed for TPC among the extracts of both varieties. Total phenolic contents of all extracts were in the range of 31.25- 62.60 $\mu \mathrm{g} \mathrm{GAE} / \mathrm{mg}$ of dry weight (DW). The ethanol extracts of both varieties showed highest content, and it was 62.60 and $56.65 \mu \mathrm{g}$ GAE/ mg of dry weight for GOJNEE and TIA, respectively (Table 5). TPC was found in the extract of ethyl acetate and petroleum ether as 45.9 and $39.8 \mathrm{in} \mathrm{GOJNEE}$, and $41.35 \mathrm{and} 31.25 \mu \mathrm{g} \mathrm{GAE} / \mathrm{mg}$ of dry weight (DW) in TIA, respectively (Table 5).

Table 5: Phenolic contents of different extracts of two selected variety of $M$. charantia

\begin{tabular}{|l|l|l|}
\hline Variety & Extracts & Total phenolics $\boldsymbol{\mu g}$ GAE/mg DW \\
\hline \multirow{4}{*}{ GOJNEE } & Ethanol & $62.60 \pm 1.09$ \\
\cline { 2 - 3 } & Ethyl Acetate & $45.90 \pm 1.49$ \\
\cline { 2 - 3 } & Pet. Ether & $39.80 \pm 2.54$ \\
\hline \multirow{3}{*}{ TIA } & Ethanol & $56.65 \pm 1.04$ \\
\cline { 2 - 3 } & Ethyl Acetate & $41.35 \pm 1.45$ \\
\cline { 2 - 3 } & Pet. Ether & $31.25 \pm 2.69$ \\
\hline
\end{tabular}

Values are means $(n=3) \pm$ SD. Here, all values are statistically significant at the $5 \%$ level.

\section{DISCUSSION}

The population of the world is increasing rapidly and creates many serious problems like resources deficiency, food and feed shortage. At present food shortage is a prime challenge for nutritionist to provide more and more protein rich food for growing population. Plants food such as fruits and vegetables are plying a vital role in the diet of human being since centuries, providing enough quantity and quality of fat, protein, carbohydrates, vitamins and minerals (Noomrio, 1956).

Moisture plays an important role in the growth activities of trees. It is also essential for most of the physiological reactions in plant tissue and in its absence, life does not exist (Rangaswami, G; 1976). The moisture content of the hybrid variety TIA $(94.06 \%)$ was higher than that of GOJNEE $(93.2 \%)$. The moisture content of karela was reported to be 91.2\% (Soomro and Ansari, 2005). The differences in the moisture content between the $M$. charantia hybrid varieties can be attributed to the difference in the genetic composition and also the agro-cultural practices.

The ash content in GOJNEE variety $(0.95 \%)$ was higher than Tia $(0.79 \%)$ variety. The low ash content reflects that the mineral contents preserved in the food materials is also low. The result therefore suggests a low deposit of mineral elements in the fruit. (Antia et al., 2006).

The crude protein content in GOJNEE variety (1.02\%) was slightly higher than TIA variety $(0.9 \%)$. The proteins and carbohydrates present in the plant may be a conglomerate of bioactive sugars, glycoproteins or proteins which gives the plant its medicinal potency against certain diseases (Srivastava et al., 1989; Hokputsa et al., 2004). The protein content of hybrid bitter gourd reported to $1.9 \%$ by Soomro and Ansari (2005) which is very similar to our result.

Pectin, cellulose, hemicelluloses together with lignin is classified as dietary fibre (Robinson and Lawler, 1980). The crude fibre content between the two varieties revealed that the higher content was in GOJNEE variety $(2.19 \%)$ than in TIA variety $(1.25 \%)$. Intake of bitter gourd pericarp with high dietary fibre content may have positive health benefits possibly for reduction of colon cancer risk, diabetes, obesity, hypercholesterolaemia, gallstones and constipation (DeVries, 2003; Kritchevsky, 1988; Takeyama et al., 2002).

The value of the crude fat for GOJNEE variety $(0.6 \%)$ was lower compared with TIA variety $(0.81 \%)$. In 2005 , Soomro and Ansari reported that hybrid green bitter gourd contained $0.4 \%$ fat which is near about our result. This result suggests that bitter gourd is not good source of lipid. Dietary fats function through increase of palatability of food by absorbing and retaining flavours (Antia et al., 2006).

Minerals are called a "spark plugs of life" because they are required to activate hundred of enzyme reactions within the body. Life is dependent upon the body's ability to maintain balance among the minerals (Watts, 1997). In this study, the elements such as $\mathrm{Ca}, \mathrm{K}$ and $\mathrm{Fe}$ found in reasonable amount while $\mathrm{Mg}$, $\mathrm{Cr}$ were relatively low in both varieties. This supports the previous data on M. charantia (Wills et al., 1984 and Yuwai et al., 1991).

The Ca was found at higher amount in GOJNEE variety $(2.35 \mathrm{ppm})$ than TIA variety (2.24 ppm). On the other hand, high amount of $\mathrm{Ca}$ was found in bitter gourd as $137.69 \mathrm{mg} / 100 \mathrm{gm}$ reported by Soomro and Ansari (2005). The actual reason is unknown, and may be the environmental and soil factors are responsible for this difference. 
Between the both varieties higher amount of $\mathrm{K}$ was recorded from variety GOJNEE 0.84 ppm than the TIA variety $(0.78 \mathrm{ppm})$. potassium helps in release of chemicals which acts as nerve impulses, regulate heart rhythms, deficiency causes nervous irritability mental disorientation, low blood sugar, insomnia and coma (Takeyama et al., 2002).

Iron content of $M$. charantia was 1.04 and $0.87 \mathrm{ppm}$ in GOJNEE and TIA variety, respectively. It plays a significant role in oxygen transport in the body. Iron deficiency causes anaemia, weakness, depression, poor resistance to infection (Trease et al., 1989)

The amount of the $\mathrm{Mg}$ for GOJNEE variety $(0.57 \mathrm{ppm})$ was lower compared to TIA variety $(0.64 \mathrm{ppm}) . \mathrm{Mg}$ plays important role in formation and function of bones, muscles and prevents high disorders, high blood pressure and depression (Underwood et al, 1999) also Mg plays important role in enzyme activity.

The $\mathrm{Cr}$ was found least amount in both varieties (0.0037 and $0.0024 \mathrm{ppm}$ for GOJNEE and TIA variety, respectively). $\mathrm{Cr}$ is vital element as it works with insulin to stabilize blood sugar level, helps to absorb energy from blood and increase muscle mass reducing fat mass in human body (Verma et al., 1956). Deficiency of Cr results in growth failure, cataract, hyperglycemia, neuropathy, atherosclerosis and leads to diabetes in human (Watts, 1997).

Phytochemical screening of these two varieties of $M$. charantia revealed the presence of alkaloids, flavonoids, saponins and tannins. These results are in correlation with the previous work on M. Charantia (Weight et al., 1992). The presence of these secondary metabolites in the fruits of $M$. charantia may contribute to its medicinal value. It has already been reported that the extract of crude bitter gourd is used for different disease such as disease of liver and pancreas, analgesic, anti-inflammatory, reduces cholesterol level, promotes appetite and supports blood sugar managing for diabetes or people with high risk of developing diabetes (Verma and Aggarwal, 1956).

The protective and metabolic role of alkaloids in animals has been documented (Edeoga and Eriata, 2001). It is known that Saponins inhibit $\mathrm{Na}^{+}$efflux by blockage of the influx of concentration in the cells, activating a $\mathrm{Na}^{+}-\mathrm{Ca}^{2+}$ antiporter in cardiac muscles. The increase in $\mathrm{Ca}^{2+}$ influx through this antiporter strengthens the contraction of heart muscles (Bligh et al., 1959). Flavonoids may help to protect against oxidative stress induced diseases through contributing along with other antioxidant vitamins, and enzyme to the total antioxidative defense system of the body. Many studies have attributed that antioxidant properties are due to the presence of flavonoids (DeVries et al., 2003).

The present study estimated the phenolic content in the extract of ethanol, ethyl acetate and petroleum ether of $M$. charantia. Our results showed that ethanolic extract contained higher phenolic content $(62.60 \mu \mathrm{g}$ GAE/mg DW) than other two extracts, and GOJNEE variety contained higher phenol levels than TIA. This variation, even within the same variety, depends on many factors including environmental factors, maturity, location, and soil condition. Recent studies have shown that fruit and vegetable`s phenols and polyphenols such as flavonoids are one of the major groups that indicate a large spectrum of biological activities that are principally ascribed to their antioxidant property. They prevent free radical damage and lipid peroxidation (Bernardi et al., 2008; Akhila et al., 2009). The high content of total phenolic components in the ethanolic extract may have led to the better results found in the total antioxidant activity and free radical scavenging ability when compared with other two extracts.

\section{CONCLUSION}

Based on the result of our findings, it can be concluded that GOJNEE hybrid variety of M. Charantia contains better amount of nutrients and minerals than TIA variety which can contribute to the nutrient and energy requirement of human body. Most of the extracts of the two hybrid varieties contains same types of phytochemicals. Between the extracts of two varieties, the highest total phenolic content was found in ethanolic extract of GOJNEE variety which may have the potential for application in food systems to maintain food quality. Further study is necessary to elucidate detail medicinal values of $M$. charantia, then it would be possible to utilize this vegetable effectively.

\section{REFERENCES}

- Akhila, S., Bindu, A., Bindu, K., \& Aleykutty, N. (2009). Comparative evaluation of extracts of Citrus limon burm peel for antioxidant activity. Journal of Young Pharmacists, 1(2), 136.

- Antia,B.S., E.J. Akpan, P.A. Okon and I.U. Umoren, (2006). Nutritiveand Anti-Nutritive Evaluation of Sweet Potatoes (Ipomoea batatas) Leaves. Pak. J. Nutr., 5: 166-168.

- AOAC, (1960). Official and Tentative Methods of Analysis. $9^{\text {th }}$ edition, Association of Official Analytical Chemists, Washington DC., pp: 73.

- AOAC, (1980). Official Methods of Analysis, $13^{\text {th }}$ edition, Association of Official Analytical Chemists, Washington, DC, USA.

- AOAC, (1995). Official Methods of Analysis. Association of Official Analytical Chemists, Washington, DC, USA.

- $\quad$ Barua,R., Sultana, S., Talukder.,U.E.M., Chakma, K., Hasan, M.M.C., and Islam, S.M. 2014. Antioxidant and Cytotoxic activity of Crude Flavonoid fraction from the fruits of hybrid variety of Momordica charantia (Bitter Gourd). British Journal of Pharmaceutical Research, 4(7): 778-786.

- $\quad$ Basch, E., Gabardi, S., \& Ulbricht, C. (2003). Bitter melon (Momordica charantia): A review of efficacy and safety. American Journal of Health-System Pharmacology, 60(4): 356-359. 
- $\quad$ Behera,T. K., Staub,J.E., Behera., S and Simon, P.W.(2007). Bitter Gourd and Human Health. Medicinal and Aromatic plant science and biotechnology. Global science books.

- Bernardi, A. P. M., López-Alarcón, C., Aspée, A., Rech, S. B., Von Poser, G. L., Bridi, R., DUtrafiho, C. S. and Lissi, E. (2008). Antioxidant Activity in Southern Brazil Hypericum Species. Journal of the Chilean Chemical Society, 53(4), 1658-1662.

- Bligh, E.G. and W.J. Dyer, (1959). A rapid method of total lipid extraction and purification. Can. J. Biochem. Physiol., 37: 911-917.

- Boham,B.A., \& Kocipai-Abyazan, R. (1974). Flavonoids and condensed tannins from leaves of Hawaiian vaccinium vaticulatum and V. calycinium. Pacific sci, 48, 458-463.

- DeVries, J. W. (2003). On defining dietary fibre. Proceeding Nutrition Society, 62, 37- 43.

- Edeoga, H.O., Okwu, D.E and Mbaebie, B.O (2005). Phytochemical constituents of some Nigerian medicinal plants. Afr. J. Biotechnol., 4(7): 685-688

- Edeoga HO, Eriata DO (2001). Alkaloid, tannin and saponin contents of some Nigerian medicinal plants. J. Med. Aromatic Plant Sci., 23: 344-349

- Harborne, J.P. 1991. Phytochemical Methods. 2nd Ed., Oxford University Press, London.

- Harborne, J.B., (1973). Phytochemical Methods: A Guide to Modern Techniques of Plant Analysis. $2^{\text {nd }}$ edition, Chapman and Hall Publishers, New York, pp: 85.

- Hokputsa S, Harding SE, Inngjerdingen K, Jumel K, Michaelsen TE, Heinze T, Koschella A, Paulsen BS (2004). Bioactive polysaccharides from the stems of the Thai medicinal plant Acanthus ebracteatus: Their chemical and physical features. Carbohydr. Res., 339(4): 753-762.

- Joseph, B and Jini, D. (2013) Antidiabetic effects of Momordica charantia (bitter melon) and its medicinal potency. Asian Pacific Journal of Tropical Diseases, 3(2): 93-102. https://dx.doi.org/10.1016\%2FS2222-1808(13)60052-3

- $\quad$ Kritchevsky, D. (1988). Dietary fibre. Annual Review of Nutrition, 8(1): 301-328

- Marr, K. L., Mei, X. Y., \& Bhattarai, N. (2004). Allozyme, morphological and nutritional analysis bearing on the domestication of Momordica charantia L. (Cucurbitaceae) from China, Laos, and Nepal. Economic Botany, 58(3), 435-455.

- Mills, D.F (1981). Symposia from the XII International congress on Nutrition Prog. Clin. Biol. Res. 77 : 165 71.

- Noormrio, M.H., Dahot, M.U., Siddiqui, H.L., Dewani, V.K (1996). Studies on the nutritive composition of Phyllanthus multiforus (Kanoo) fruit. Sci. Sindh, 3: 13-19.

- Petersen, L., (2002). Analytical methods: Soil, water, plant material, fertilizer. Soil Resources Management and Analytical Services, Soil Resource Dev., Inst. Danida, Dhaka.

- Obadoni, B.O. and Ochuko, P.O. (2001). Phytochemical studies and comparative efficacy of the crude extracts of some homeostatic plants in Edo and Delta States of Nigeria. Global J. Pure and Appl. Sci. 8:203-208.

- $\quad$ Rangaswami, G. (1976). Sericulture manual mulberry cultivation, FAO, UN. Rome PP. 68-72.

- Robinson, C. H, and Lawler, M., (1980). Normal and therapeutic Nutrition. Macmillan Co Ltd., New York.

- Sofowora, A (2006). Medicinal Plants and Traditional Medicine in Africa. $2^{\text {nd }}$ edition, Spectrum Books Ltd., Ibadan, Nigeria. pp. 151-153, 209-214.

- Soomro, A.K. and K.A. Ansari, (2005). Medicinal use of bitter gourd (Momordica charantia L.) in District Sukkur, Sindh, Pakistan. Hamdard Med. 48: 9-14.

- Srivastava, R., Kulshreshtha, D.K (1989). Bioactive polysaccharides from plants. Phytochem., 28(11): 2877 2883.

- Takeyama, E., Fukushima, M., \& Tanimura, A. (2002). Effect of heat-treatment on the content and polysaccharide composition of dietary fibre. Food Science and Technology Research, 8(2), 125-130.

- $\quad$ Trease, G.E. and W.C. Evans, (2002). Pharmacognsy. $11^{\text {th }}$ edition, Macmillian Publishers, UK.

- Underwood, E.J and Suttle NF (1999). The mineral nutrition of Livestock, CABI publishing, New York. pp 51 101.

- Ullah, M., Chy, F. K., Sarkar, S. K., Islam, K. M. and Absar, N. (2011). Nutrient and Phytochemical Analysis of Four Varieties of Bitter Gourd (Momordica charantia) Grown in Chittagong Hill Tracts, Bangladesh. Asian Journal of Agricultural Research, 5(3):186-193.

- Verma, J.P. and J.S. Aggarwal, (1956). A note on component fatty acids of the oil from the seed of Momordica charantia L. J. Indian Chem. Soc., 33: 355-357.

- Watts, D.L., (1997). Trace Elements and Other Essential Nutrients, Clinical Application of Tissue Mineral Analysis. Writer's B-L-O-C-K, USA., ISBN-13: 978-1885676221

- Weight, L.M., Jalobes, P. and Noakes, T.D (1992). Dietary Iron deficiency and sports anemia. Brit. J. of Nutri. 68: $253-60$. 
- Wills, R. B., Wong, A. W., Scriven, F. M., \& Greenfield, H. (1984). Nutrientcomposition of Chinese vegetables. Journal of Agricultural and Food Chemistry, 32(2), 413-416.

- Yoshime,L.T.,Louise Pereira de Melo,I. L.P. D., Sattler, J.A.G., Carvalho, E.B.T and

- Filho,M.J. (2016). Bitter gourd (Momordica charantia L.) seed oil as a naturally rich source of bioactive compounds for nutraceutical purposes. Nutrire, 41:12.

- Yuwai, K. E., Rao, K. S., Kaluwin, C., Jones, G. P., \& Rivett, D. E. (1991). Chemical composition of Momordica charantia L. fruits. Journal of Agricultural and Food Chemistry, 39(10), 1762-1763. 